\title{
Policy challenges for the development of energy flexibility services
}

\author{
Erwin Mlecnik $^{\mathrm{a}, *}$, James Parker ${ }^{\mathrm{b}}$, Zheng Ma ${ }^{\mathrm{c}}$, Cristina Corchero ${ }^{\mathrm{d}}$, Armin Knotzer ${ }^{\mathrm{e}}$, \\ Roberta Pernetti ${ }^{\text {f }}$

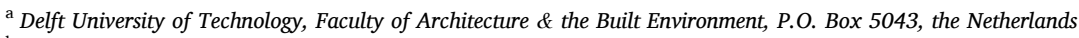 \\ ${ }^{\mathrm{b}}$ Leeds Beckett University, School of Built Environment \& Engineering, Northern Terrace, Queens Square Court, Leeds, LS2 8AG, United Kingdom \\ ${ }^{\mathrm{c}}$ University of Southern Denmark, Center for Energy Informatics, Campusvej 55, Odense M, DK-5230, Denmark \\ ${ }^{\mathrm{d}}$ IREC - Institut de Recerca en Energia de Catalunya, Jardins de les Dones de Negre 1, 2nd floor, 08930, Barcelona, Spain \\ e AEE - Institute for Sustainable Technologies, Department Building and Retrofit, A-8200 Gleisdorf, Feldgasse 19, Austria \\ ${ }_{\mathrm{f}}^{\mathrm{E} U R A C}$ Research, Institute for Renewable Energy, Via Volta 13/A, 39100, Bozen/Bolzano, Italy
}

\section{A R T I C L E I N F O}

\section{Keywords:}

Energy policy

Energy flexibility

Smart grids

Demand response

Service development

Stakeholder research

Strategic niche management

\begin{abstract}
A B S T R A C T
European energy policies call for an increased share of renewable energy sources and a more active role of the energy consumer. This is facilitated by, amongst others, buildings becoming energy flexible hubs, supporting smart energy grids with demand response strategies. While there is abundant technical research in this field, the related business and policy development is less well documented.

This research scopes existing policy programmes and identifies opportunities and barriers to business development supporting energy flexible buildings. Using examples from seven European countries, this work reviews influencing niche management factors such as existing policy instruments, business development cases and identified stakeholder concerns, using literature research, narrative analysis and stakeholder research.

National policy pathways show many differences but confirm that European buildings might become active players in the energy market, by providing energy storage, demand response and/or shifts in the use of energy sources. Slow sustained business development for energy flexibility services was mainly identified in the retail industry, and for energy service companies and aggregators. The direct involvement of end users in energy flexible buildings is still difficult. Stakeholders call for policy improvement, especially concerning the development of flexible energy tariffs, supporting incentives, awareness raising and more stakeholder-targeted business development.
\end{abstract}

\section{Introduction}

Buildings are responsible for approximately $40 \%$ of energy consumption and $36 \%$ of $\mathrm{CO}_{2}$ emissions in the EU, making them the single largest energy consumer in Europe (EC, 2018). In the EU, the residential sector represented $25.38 \%$ of the final energy consumption in 2015 (Bertoldi et al., 2018). Many factors influence the energy consumption in the residential sector, such as population size, economic development, weather conditions, occupant behaviour and an increasing use of electricity compared to gas (Bertoldi et al., 2018; Guerra Santin, 2010). Policies for improving energy performance of buildings (Beerepoot, 2007; Murphy, 2016) and policies supporting innovation development (Mlecnik, 2013; Stutvoet, 2018) can also have an effect on reducing energy demand and steering technical change. The International Energy
Agency (IEA DSM Task 25, 2018; IEA, 2019a) envisions that, next to building energy efficiency, demand side response strategies can reduce the impact of rising electricity demand, but effective policies are needed to address the current market barriers and promote investment.

Meanwhile, energy production is increasingly relying on renewable energy systems (RES). A quarter of Europe's power already comes from RES (De Groote and Rapf, 2015), and national plans forecast this proportion to rise substantially in the next decade. For instance, Denmark set a 2030 target of reaching 50\% RES by 2030 (State of Green, 2018). Italy aims for $30 \%$ RES in the Italian energy supply by 2030 as an average for electrical energy, thermal energy and transport systems (PAE, 2017). Austria's target for 2030 is $45-50 \%$ share of RES for the total gross energy consumption. Spain's target for 2030 is $42 \%$ share of RES for the final energy use. Many other countries are still identifying

\footnotetext{
* Corresponding author.

E-mail addresses: e.mlecnik@tudelft.nl (E. Mlecnik), J.M.Parker@leedsbeckett.ac.uk (J. Parker), zma@mmmi.sdu.dk (Z. Ma), ccorchero@irec.cat (C. Corchero), a. knotzer@aee.at (A. Knotzer), Roberta.Pernetti@eurac.edu (R. Pernetti).
} 
their RES targets.

A challenge is that future electricity grids and heat networks will have to operate in a reliable manner, producing relatively constant voltages and temperatures, despite the fluctuating input from RES. Grid flexibility, which can come from various sources, is required to facilitate high penetration of wind and solar energy (Denholm and Hand, 2011). Grid developers consider buildings to be a future part of the energy systems: buildings can manage their thermal and electrical loads in a flexible manner and thus provide flexibility services to the energy systems. A more active role for buildings within the energy market is still a key innovation to be unlocked, with a potentially large value to be captured (De Groote and Rapf, 2015). Buildings have a potential to become micro energy hubs consuming, producing, storing and supplying energy in a flexible manner.

Future strategies to ensure the security and reliability of energy supply will need to involve simultaneous coordination of building's distributed energy resources, energy storage and flexible, schedulable loads connected to distribution networks (Jensen et al., 2017; Ma et al., 2019). How to provide such Energy Flexibility in Buildings and smart energy grids was investigated in many research projects, mainly from the viewpoint of electrical power engineering of energy systems and energy storage (Giordani et al., 2013; IEA EBC Annex 67, 2019). Typical technical energy flexibility solutions include for example the control of heat pumps, district heating, HVAC systems, photovoltaics and lighting with sources of energy flexibility coming from batteries, water storage, thermal storage in building material and fuel switches (Jensen et al., 2019).

Most demand side management (DSM) policies (funding, subsidies, rules and legislation, as well as other forms of support) were developed to support the creation and uptake of single products and technologies, not services (IEA DSM Task 25, 2018). DSM services can relate to both Energy Efficiency and Demand Response; such services have so far mainly focused on electricity system operation, generation, transmission/distribution, energy retailing and load (Behrangrad, 2015).

While literature abundantly shows that progress can be expected regarding RES and DSM, the required service and policy development for Energy Flexible Buildings (EFB) is less well documented. Policy development is needed to support the integration of technologies and processes for 'energy smarter' buildings and communities. To facilitate such policy development, it is important to understand the perspectives of multiple stakeholders, the scope of existing policy programmes, and market development drivers and barriers, as for example those experienced by innovation champions, to identify and remove obstacles to market penetration of supporting technologies and processes.

\section{Research goal and question}

The goal of this research is to better understand European innovation challenges and opportunities for introducing energy flexible buildings as active DSM instruments in future smart grids. Particularly, this research aims to better understand the way existing policies relate to EFB, and to identify stakeholders' perceived barriers and opportunities for the development of energy flexibility and how these experiences can help develop policies. The main research question is:

How can policy remove barriers for the development of commercial services for energy flexible buildings?

The work presented in this paper analyses this qualitative question with a triple-helix approach covering multiple European countries and reviewing existing policy instruments, analysing business development of energy flexibility services and discussing stakeholder concerns. The research first identifies what current national policies stimulate the development of EFB and further analyses what barriers and opportunities can be identified from market frontrunners. The results are then discussed from various stakeholder perspectives, finally resulting in energy and innovation policy recommendations.

\section{Research method}

As the advent of EFB can be considered a strategic niche development, strategic niche management (SNM) is used as a theoretical framework for analysis. The SNM theoretical framework is wellestablished (Van de Belt and Rip, 1984; Kemp, 1994; Kemp et al., 1998; Rotmans et al., 2000; Schot and Geels, 2008) and is well-suited for this analysis, as it covers aligning processes at multiple levels (policy, industry, technology, user preferences.), aiming at principles to improve the chance of diffusion of innovations. SNM scholars analysed successes and failures of innovation trajectories involving, for example, energy systems (Raven, 2005; Hendry et al., 2007; Woei, 2007; Verbong et al., 2008) and energy-efficient housing (Smith, 2007; Mlecnik, 2014). SNM literature regarding niche development for energy flexibility services is scarce. On a more holistic level, some authors advocate using decentralized models of ownership for distributed energy systems, developing services involving multiple agents or exploiting demand side or aggregator business models (for example: Meadowcroft, 2009; Behrangrad, 2015; Heleno et al., 2016; Koirala and Hakvoort, 2017; Ma et al., 2017).

The theory is used to detect factors from current policy pathways, innovation journeys and stakeholder concerns in the energy and building service sectors in the seven countries. The research does not focus on technology assessment and does not attempt to provide a conclusive answer to the question of what is the best strategy for market niche entry or policy development; rather it seeks to review and integrate experiences, which may help to understand the barriers for the market development of services for EFB, particularly regarding key SNM features, such as the formulation of expectations and visions, and requirements for learning, innovation and policy changes.

This paper is based on policy literature study and qualitative research using narrative analysis of presentations of institutes, businesses and policy makers in European countries. Narrative analysis is suited to analyse the question as it captures the stakeholders' views and memories of the moment, this means during the emergence of experiments and first market experiences for EFB. A disadvantage of this method is that the narratives of businesses and policy actors might be influenced by their personal experience, wishes and beliefs. This is countered by reflecting their views on the narratives from scientists and researchers, which to a certain extent might be less biased.

Seven countries (Austria, Belgium, Denmark, Italy, The Netherlands, Spain and the UK) were chosen based on various stages of policy development and availability of qualitative research on the subject. For example, public consultation on EFB was organized in these countries in the period 2015-2019, and interviews and stakeholder meetings were held. The selection includes Denmark, which has a long tradition of setting ambitious national energy targets and is now widely recognised as a global leader in integrating variable renewable energy (IEA, 2019b). Also, an energy flexibility service market and policy development is present in the UK and Spain. Other countries can be seen as later adopters where policy is lagging behind market aspirations. While Austria shows market development, other countries still have important barriers related to initiating EFB, such as: a low ambition level regarding renewable energy share (Belgium), a closed flexibility market (Italy), a relatively small renewable energy supply (The Netherlands).

As a reflection base, various sources are used resulting from the IEA EBC Annex 67 working group 'Energy Flexible Buildings', which mainly consist of researchers and scientists. The aim of IEA EBC Annex 67 (2019) was to increase the knowledge, identify critical aspects and possible solutions concerning EFB and the means to exploit and control this flexibility (Jensen et al., 2017). These sources include Annex meeting minutes, newsletters, notes, scientific articles and Annex reports. Amongst others, 13 researchers summarized stakeholder experiences in a report covering 16 cases analysing viewpoints from educational, retail and office building stakeholders as well as households (Ma et al., 2019). Although the Annex work did not focus on studying policy recommendations per se, a policy discussion is produced 
from analysing the stakeholder data from the research question perspective.

In Section 4, an overview is presented of existing supporting policy instruments in the seven countries. In Section 5 experiences from market frontrunners are presented, focusing on perceived barriers and opportunities. In Section 6 the observations are discussed in terms of needs of stakeholders for developing policy related to EFB. The concluding section frames all experiences in general policy recommendations.

\section{European policies supporting the development of energy flexible buildings}

To investigate where policy currently supports the development of $\mathrm{EFB}$, the evolution of policies applied in the EU and in the seven countries in the period 2015-2019 is discussed.

European policies are already actively promoting energy flexible solutions. In its efforts to reduce carbon emissions, the European Commission has long advocated the need for energy security and energy savings in buildings, resulting in a legislative framework that includes, amongst others, the European Performance of Buildings Directive (published in 2002 and revised in 2010) and the Energy Efficiency and Renewable Energy Directives. The recently introduced Clean Energy For All Europeans Package (EC, 2016) updates all energy policies and adds new rules, which were formally adopted in 2019 (EC, 2018) as part of delivering on the EU's Paris Agreement commitments. The new EU policy developments are to be implemented in Member States in the coming decades and aim to empower European consumers to become fully active players in the energy transition, providing them with more choice and better feed-in rights, to modernize the EU electricity market towards flexibility, and to establish an obligatory renewable energy target of at least $32 \%$ and an energy efficiency target of at least $32.5 \%$, with a possible upward revision in 2023 (EC, 2018). An underlying motive is that consumers who benefit from appropriate energy price signals can drive the needed renewable energy investments.

The package is currently impacting revisions of the Energy Performance in Buildings Directive (EPBD, 2018), the Renewable Energy Directive (RED, 2018), the Energy Efficiency Directive (EED, 2018) and the EU Governance Regulation (GEU, 2018) with expected changes in 2019 for the Electricity Directive, Electricity Regulation, Risk-Preparedness Regulation, and Regulation for the Agency for the Cooperation of Energy Regulators (ACER). Another EU objective is to introduce a Smart Readiness Indicator for Buildings, for which options are being explored (SRI, 2018; Pernetti et al., 2017).

It is expected that all these European Regulations and Directives will directly influence national policy development. Besides EU initiatives, national policies have also evolved in the period 2015-2019 to support the energy transition, particularly in the building and energy sectors. The following paragraphs illustrate policies in the selected countries that influence the development of EFB.

Denmark has introduced ambitious national climate goals (Danish Government, 2013; IEA, 2019b) and facilitating policy for EFB. The Danish energy agreement of 2018 underlines the objective to increase the utilisation of data and digital solutions and create a smart energy system with storage for RES (Energi-, Forsynings-og Klimaministeriet, 2018). Meanwhile, all consumers will have smart meters by 2020, giving customers an opportunity to participate in the Nordic spot market. Real-time energy pricing is possible in Denmark if the supplier offers this service. Electricity suppliers can become an aggregator or they can outsource this service. To be a third-party independent aggregator, the company needs to register as a Balance Responsible Party (BRP) or be in a contractual relationship with one. Furthermore, incentives stimulate electricity use: the Danish Public Service Obligation (PSO) tax (in the Electricity price) will be fully removed from the electricity price in 2022 , and the Danish government wants to reduce the electricity levy by almost one third. The Danish government has agreed to spend $€ 17,500$, 000 on large-scale energy storage projects (Copenhagen Capacity,
2018).

In the UK, the "Smart Systems and Flexibility Plan" (HM Government, 2017a) aims to: remove barriers to smart technologies, including energy storage systems; enable smart homes and non-domestic buildings (referred to as 'businesses'); and to create markets that allow for and incentivise energy flexibility. This plan allows access to fair financial returns for providers engaged in flexibility services such as storage or demand response. The plan (HM Government, 2017a) and the progress report (HM Government, 2018) included a range of practical examples of initiatives and have led to initial market uptake of energy flexibility. The Electricity System Operator has committed to receiving $30-50 \%$ of competitive tenders from demand side flexibility by 2020 (HM Government, 2018). As part of a move towards Distribution Network Operators (DNOs) becoming Distribution System Operators (DSOs), DNOs have already issued tenders for flexibility focused network issues (HM Government, 2018). Also, the installation of smart meters in buildings, which provide the basis for consumers to participate in a half-hourly market, has been relatively successful in the UK. (HM Government, 2018). Aggregators' access to the market has been opened through changes made to the UK Balancing and Settlement Code (BSC) and the Grid Code, allowing Aggregators access to the Balancing Mechanism (HM Government, 2018).

In Spain, the Ministry for the Ecological Transition developed the National Integrated Plan for Energy and Climate 2021-2030 (PNIEC, 2019). It describes various initiatives for supporting energy efficiency measures in buildings, and introduces obligations and economic incentives for reaching net zero energy buildings (obligation for new public buildings since 12/2018; for all new buildings since 12/2020). Supporting research and innovation will focus on the flexibility and optimisation of the different sources, including topics such as demand participation in the system operation, and the needed investment in national industry developing the enabler technologies. A remarkable policy initiative is the new regulation for self-consumption and energy communities, launched in 2019, which enables and promotes the installation and sharing of PV and storage solutions (IDAE, 2019). Self-consumption regulation allows the installation of electrical storage systems to decrease contracted maximum power and demand peaks by means of storing the local generated PV surplus and using it when needed; energy arbitrage is not directly regulated neither forbidden. Additionally, this regulation facilitates the energy communities creating an aggregator agent, as well as the changes needed in the electricity market for enabling demand response. A public consultation will be launched by the Iberian Market Operator.

In Austria, the first relevant initiative for energy flexibility is the Austrian Climate and Energy Strategy, called "mission2030" (BMNT/BMVIT, 2018), where the federal government states that the energy market design of the future should enable companies to market their flexibility; generally "flexibility" is addressed 24 times to introduce a future flexible energy system. The second is the Energy Research and Innovation Strategy for Austria (BMVIT, 2017), which launches a topical energy research area "Buildings and urban systems," envisioning new buildings to have greater energy flexibility, and being able to adapt their energy consumption to the sources available at any given time. The third is an industry and public initiative via the Technology Platform Smart Grids Austria (TP SGA, 2019). The aim of the platform is to pool joint forces for future intelligent electricity grids, also linked to smart grid projects and other industry initiatives in this field. Austria offers funding mechanisms to include battery systems into the building energy systems via national or local governments and plans to abolish the solar tax on photovoltaic self-consumption from 2020.

The current Italian regulation (National Decree n.28/2011: MED, 2018) requires that all new buildings and major interventions integrate RES, to cover at least 50\% of annual energy consumption for heating, domestic hot water preparation and cooling. Coupled with the national Plan for uptake of nZEBs (National Decree 06/2017: MED, 2017), this fosters the diffusion of distributed energy production systems. Like in 
many countries, feed-in revenues are given to building users according to the amount of energy delivered and the installed power, without consideration of the daily energy production, seasonal variations or stress caused on the energy grid. The optimisation of the energy use through energy flexibility, which is potentially allowed by the law, is thus not fostered by the Net metering Scheme and not widely applied. Most regulatory schemes are based on the one-to-one consumption model (i.e., self-consumption) and do not allow for the introduction of aggregation models for enabling energy communities and energy flexibility at cluster scale (Chiaroni et al., 2018). Future schemes might allow for a more open energy market, since the National Regulation Authority for Energy, Grid and Environment has recently launched a series of pilot cases for implementing different aggregation models (ARERA, 2018). Regional contributions allow for a non-repayable funding of $50 \%$ of the installation costs of battery systems, towards a maximum amount of $€ 3000$. At national level, there is the will to establish an incentive framework to reach the objective of reaching 6000 MW storage by 2030 .

In Belgium, PV systems on buildings can also benefit from feed-in tariffs. The Flemish transition arena "New Energy Demand and Delivery 2025" specified the need to transform to a new energy system in Flanders within the EU context (VRWI, 2014). Captains of industry expect that nuclear power generation will be abandoned and that new energy systems will include interaction between energy demand, supply, storage and grids. A highest priority was given to develop storage systems (VRWI, 2014: 226), for example, via solar boilers, building integrated thermal storage, geothermal solutions, batteries and the development of related control systems. However, these are not yet at full market maturity (De Groote and Rapf, 2015) and energy flexibility services and networks still need to be developed. Digital energy meters are still being implemented. Belgium proposes an $18.3 \%$ share of energy from RES in gross final energy consumption in 2030 (EC, 2019).

In The Netherlands, the installation of PV on buildings, feed-in tariffs and development of RES in adjacent postal code districts are supported by policy. The knowledge and innovation agenda (TKI Urban Energy, 2015) defines a Dutch vision for 2016-2019 for developing innovations for solar energy supply, heat and cold, energy saving, integration and intelligent control of energy systems in the built environment. It suggests that the classical energy supply and demand system should be abandoned, in favour of central RES (wind, hydro, large solar and bio-energy), connected local RES, energy storage using heat, cold, and electricity (also in vehicles), data management and control, and smart grids that offer variable rates and tariffs. Market actors support this move and advocate a gas-free built environment, DSM, flexible energy systems and large storage capacity. Energy Storage NL (2019) points out current policy barriers for electricity storage systems, such as the double energy taxation (for loading and unloading) and the lack of renewable energy certificates for energy coming from storage systems. From July 1 , 2018, the Dutch Government abandoned the obligation of a gas supply connection for (small) new buildings (WetVET, 2018). The revised Dutch Heat Law (2019) allows the Authority Consumer and Market to maximise tariffs according to heat supply temperature and facilitates the participation of renters and owners' assemblies in the heat market. Furthermore, local authorities have been urged to develop urban heat development plans and strategies for the energy renovation of neighbourhoods.

The above describes a variety of policy instruments, and countries developing their markets and policies at different speeds. The supply sector is also challenged in various manners to organize demonstrations and business models. While many policies highlight the importance of changing energy generation, distribution, storage systems and market (players), the role of buildings is rarely expressed in policies. European buildings are nevertheless becoming active players in the energy market due to these policy changes, and are expected to play a key role in solving energy demand and supply issues, using solutions that provide better energy efficiency, energy storage, demand response or shift in energy source. The next section discusses barriers and opportunities for development of energy flexibility services for buildings, as observed by market frontrunners.

\section{Experiences from service development for energy flexible buildings}

Workshops (see addendum), interviews and field notes regarding EFB realized in the period 2015-2019 were analysed to better understand why and how energy demand stakeholders, and intermediaries between energy supply and demand, engage in providing energy flexibility services to grid operators and what they perceive as main policyrelated problems. Most business development examples were found in the retail industry, and for energy service companies and aggregators. While research can provide a lot of examples of emerging strategies being tested in the market, the following describes what type of energy flexibility services were sustained after testing and monitoring.

\subsection{Retail industry}

It was found that some retailers are willing to participate in the implicit demand response by energy control of their buildings. For example, one Dutch (retail) store made a (temporary) contract with the local distribution net manager and now provides energy flexibility to the electricity network. The underlying motive for the energy network manager was that the existing grid operator experienced difficulties to provide sufficient capacity on time in an urban area where new construction was already planned: to avoid investing in grid reinforcement the network manager wanted to introduce energy flexibility in collaboration with neighbouring companies. They found a retail store that, at an agreed cost, now provides energy flexibility by storing energy in batteries or temporarily lowering freezing temperatures. The collaborating stakeholders did not find a solution to enforce limitation of energy use, neither did they find a legal way to share risks in grid operation.

Similar examples were found in other countries. Overall, influencing factors for retailers to participate in the demand response are related to, for example, whether the demand response participation matches the company goals, influences business operation, and whether retail industry lacks related knowledge (Ma et al., 2019). By comparing Denmark and the Philippines, Ma et al. (2019) also found that there are cultural differences regarding the energy control preferences and concerns in retail industry, but there were no significant differences regarding the employees' and customers' engagement.

\subsection{Energy service companies (ESCOs)}

ESCOs have been developed that finance Energy Performance Contracts (EPCs) through third party financing (TPF). In the past, this business model has been applied successfully for implementing for example relighting and (low-hanging fruit) energy saving measures. ESCO markets are driven by market forces as much as by dedicated policy measures (Bertoldi and Boza-Kiss, 2017). Currently ESCOs are considering services for deep renovations and demand side services. However, ESCO development has been limited due to capacities for ESCOs to create financing options for EPCs as well as the limited participation of third party financing entities (Laffont-Eloire et al., 2019). A closer collaboration with energy actors might strengthen the ESCO market for flexibility services.

In Austria, some companies offer flexible or "floating" energy tariffs, which are hourly, daily or monthly adjusted. For a flexible hourly tariff, there are 24 new prices per day, based on a detailed weather forecast and determined the day before on the stock exchange. Other, innovative models, introduce a shared "energy community" for private PV system operators, in which they can self-consume PV power, but also store surplus energy to consume it later without additional costs, except for a community charge. Often this requires the companies to establish joint ventures between local or regional utilities (electricity grid operators 
and producers) or to extend their services to other branches, e.g., contracting of energy plants, energy saving contracting or energy auditing.

A few bigger companies offer all-in-one "energy contracting" for heating and cooling, including electricity supply using their own tariff models. In the last ten years, companies offering different smart grid services for both power and district heating, for example in Denmark, have evolved with services like forecast-based, user adaptive and selflearning control systems, using swarm control to forecast load and flexibility. A lot of these companies offer comfort automation systems along with their other service products.

In Spain, ESCOs devoted to public building management are participating in research projects to learn how to manage and implement measures that enable demand side participation in the energy systems, mainly based on existing PV installations with potential surplus (REFER, 2019). Some joint actions between ESCOs and DSOs have been presented to the public energy communities' call to test new services and business models under the energy market operator (OMIE) guidelines.

\subsection{Aggregators}

Related to policy, the market for aggregators develops at different speeds in different countries. In some countries aggregators already exist in the balancing market. European aggregators base their activity mainly on industry or tertiary buildings. For example, in The Netherlands, an aggregator, a car company and a power electronic company have built up a system based on PV panels and second life EV batteries, which will perform peak shaving during high demand events at a large event location and will offer frequency regulation services when not providing these functions.

Perceived barriers are different in different countries i.e., in the Austrian wholesale market no aggregators are seen yet, though demand response could access the EPEX day-ahead market in principal. The individual load in an aggregator pool must be prequalified separately for each consumer, which makes the process inconvenient. Furthermore, all consumers need to install an expensive phone line to participate in the balancing market. All this increases the cost for each consumer's participation, and the process leads to a reduction of the pool size. An independent third-party aggregator needs to be contracted with the $\mathrm{BRP} /$ supplier.

In the UK relatively more aggregators actively participate in the energy system. UK customer surveys show that the main motivation for participating in demand services through an aggregator is to generate incomes from existing assets such as backup generators, CHP or renewable generation, and the main barriers are insufficient rewards and regulatory uncertainty.

Overall, the aggregators are confronted with numerous regulatory barriers. Contract signature management can cause competition issues (when retailers or ESCOs are involved) or administrative complications (caused by the high number of contracts to be signed with different stakeholders). Also, the energy systems and markets lack regulation on the share of unbalance costs, their market rules conflict with those for grid operators when activating balancing services, and the technical requirements for providing these services (historically defined for traditional generation plants) are preventing the development of the aggregator business model (Ma et al., 2019).

Schultz (2019) showed that the aggregators' roles and responsibilities must be clearly defined and standardized to create the business opportunities for EFB. A single but potentially useful demand response service product cannot succeed unless the market is well-functioning across all parts of the value chain. Market conditions enabling explicit demand response in the electricity markets are needed; electrification and sector coupling is necessary to improve the economic benefit of demand response; the electricity prices should reflect the market price and grid conditions by introducing different tariff models, removing or lowering taxes. A challenge is to aggregate different flexibility providers (loads and/or Distributed Energy Resources), allowing aggregators to participate in different electricity markets (Behrangrad, 2015).

\section{Discussion}

Overall the number of cases found where energy flexibility was introduced in services for buildings was very low. Only a few buildings were detected where users kept energy flexibility in operation after simulation and testing. This may be due to energy savings not being realized, cost savings being too low or presented customer values being unattractive. A reoccurring issue is that most introduced business models remain experimental and that in countries where policy facilitates the introduction of energy flexible solutions, the market niche appears sooner.

To date, energy flexibility policy initiatives have led to commercial service development mainly in the retail sector, and for ESCOs and aggregators. New market players have appeared that offer energy contracting, balancing services or demand response services to building stakeholders such as retailers, as well as district stakeholders, such as energy communities. In theory ESCOs are well positioned to create an entry to control building devices and heating systems, but the lack of an adapted policy framework can hinder the development of flexibility services. The aggregator role can be undertaken by different stakeholders, such as existing market players or new independent aggregators, in case national policy allows such a market opening (Schultz, 2019).

Social studies (Li et al., 2017; Ma et al., 2019), show that, in theory, besides retail and commercial buildings and districts, other stakeholders might become important in the framework of the EU vision on the energy consumer. This provides opportunities for developing new business models for building owners and occupants, building, facility, asset and energy managers, consultants and suppliers. Relevant stakeholders' motivations and barriers for developing business models are summarized by Ma et al. (2019).

The direct involvement of end users in EFB appears to be difficult. Users tend to place the responsibility for the distributed energy system transitions on the national government and large energy supply utilities, and households still seem to lack willingness to invest in new distributed energy infrastructures (Seidl et al., 2019). Introducing energy flexibility can disrupt occupant lifestyles, building systems for thermal comfort and health, as well as potentially increase cost or energy consumption, and that stakeholders need to be adequately informed to support energy flexibility solutions and change behaviour (Ma et al., 2019). An important barrier for building stakeholders is that energy flexibility IT and control strategies and services are designed and installed related to building and urban characteristics, expected grid flexibility gains, the spot market and daily market, expected occupancy and changing climate conditions, which is a labour-intensive development process that requires input from multiple stakeholders. The process can be particularly discouraging for innovators when even basic facilities such as digital meters and building energy management systems are not yet installed or configured to communicate with network control systems or other buildings.

Overall, energy network managers see opportunities to collaborate with other stakeholders to realise EFB because this can reduce their investment in the networks by load levelling and load shifting. When introducing more RES, DSM also becomes crucial to guarantee the reliability of the grid. However, their vision development and learning can be hindered by slow or non-existent policy development regarding the promotion of RES and DSM.

The participation of other stakeholders in demand response services can be stimulated by their sustainability motives, but is often limited by a lack of stakeholders' knowledge and legal framework. Energy flexible solutions often have to be bespoke, which can be demotivating due to high costs for planning and renovation. The prospect of financial savings can be the most motivating factor for engaging consumers with either 
smart tariffs or appliances, with younger people, people in higher social grades, and larger households most likely to engage in energy flexible behaviour (HM Government, 2016HM Government, 2017b). However, in most countries energy tariffs are still fixed, which doesn't allow energy cost reduction when shifting energy loads.

The research presented here analysed policy and business development for $\mathrm{EFB}$, and gives a more holistic perspective of policy needs. Table 1 summarizes the main detected political, economic, social, technological, legal and environmental (PESTLE) factors that can influence future policy development that support energy flexibility services.

Both the policy and the market structure need to be redesigned for businesses and consumers to take part effectively in the energy market. The requirements and regulations for providing energy flexibility to the grid are still too complicated and too focused on traditional energy providers. There is however a good indication that the policy measures introduced in frontrunner countries are beginning to create opportunities across the markets for energy flexibility to become a viable business opportunity.

\section{Conclusion and policy implications}

This research analysed the current development of the market for EFB and supporting policies in seven European countries, covering the policy landscape development and the already developed business opportunities for energy flexibility services identifying the niche development, and discussed the observed opportunities and barriers for stakeholders.

European policy development in the field of EFB is slow and appears to be following market development and positive stakeholder confirmation. While some countries do not go beyond European objectives, others are paving the way for experimentation and energy transition with more ambitious policy initiatives that support the development of energy flexibility services. As each country has a different view on the needed policy development, networking policy makers, and crosscomparing and combining policy results can support further European development.

Compared to the technical and environmental opportunities, the market development of energy flexibility services is slow and in many countries this is because the policy does not sufficiently support the development of energy flexibility and demand side services yet. From analysing the frontrunner policies it can be expected that policy development related to increased RES, energy consumer and energy community empowerment, increased use of electrical equipment, batteries and cars, and legal frameworks for the development of virtual power plants and smart grids can push the energy flexibility market.

The niche development for energy flexibility services depends on a lot of stakeholders with different perceived needs and innovation trajectories show multiple technical, social, legal and market barriers where policy might play a role to facilitate the introduction of services for achieving EFB and districts. It is unlikely that EFB and districts can be widely introduced at this stage without revision of the policies to allow new market players to benefit from energy flexibility.

There are relatively few buildings that already operate using energy flexibility services and most of these buildings offer energy flexibility on a temporary basis. In most countries there is no clear road map yet for how the strategic niche for EFB should be developed or proceeded. Stakeholders call for policy improvement, especially concerning the development of flexible energy tariffs, supporting incentives, awareness raising and more stakeholder-targeted business development. The research shows that there is a need for supporting continued vision formation, stakeholder collaboration and networking, testing new business models, and learning from innovators and demonstration projects.

At this moment, it is important that policy makers, businesses and users continue testing multidisciplinary innovation pathways.
Table 1

PESTLE-factors for the market development of energy flexibility services.

\begin{tabular}{|c|c|c|}
\hline $\begin{array}{l}\text { Influencing } \\
\text { factors }\end{array}$ & $\begin{array}{l}\text { Most mentioned business } \\
\text { development barrier }\end{array}$ & $\begin{array}{l}\text { Most mentioned policy } \\
\text { opportunity to solve the } \\
\text { barrier }\end{array}$ \\
\hline Political & $\begin{array}{l}\text { No incentives for shifting energy } \\
\text { use in time }\end{array}$ & $\begin{array}{l}\text { Support flexible energy } \\
\text { tariffs }\end{array}$ \\
\hline Economic & $\begin{array}{l}\text { Insufficient financial benefits for } \\
\text { end users }\end{array}$ & $\begin{array}{l}\text { Devise supporting } \\
\text { incentives }\end{array}$ \\
\hline Social & Lack of knowledge & $\begin{array}{l}\text { Support awareness raising } \\
\text { and co-creation (user } \\
\text { engagement) }\end{array}$ \\
\hline Technological & $\begin{array}{l}\text { Lack of appropriate on-site } \\
\text { equipment and services }\end{array}$ & $\begin{array}{l}\text { Support new business } \\
\text { models for easy } \\
\text { installation of solutions }\end{array}$ \\
\hline Legal & Lack of user control; privacy issues & $\begin{array}{l}\text { Guarantee user override } \\
\text { and data security }\end{array}$ \\
\hline Environmental & $\begin{array}{l}\text { Lack of targets regarding } \\
\text { (primary) energy savings, } \mathrm{CO}_{2} \\
\text { emission savings or renewable } \\
\text { energy share }\end{array}$ & $\begin{array}{l}\text { Set targets and require } \\
\text { proof }\end{array}$ \\
\hline
\end{tabular}

Particularly, there appears to be a need to support better business models for achieving long-term EFB and districts beyond experimentation, and increased customer value to convince different types of stakeholders of its benefits. If building or community stakeholders are not interested in delivering energy flexibility to the surrounding energy grids, it is unlikely that in the long term buildings can be regarded as flexibility assets for the energy networks.

\section{Author contribution}

Erwin Mlecnik: Conceptualisation, Methodology, Validation, Investigation, Writing - Original draft, Writing - review and editing, Visualisation, Supervision, James Parker: Investigation, Writing - review and editing, Project administration, Zheng Ma: Conceptualisation, Investigation, Writing - review and editing, Project administration, Cristina Corchero: Investigation, Writing - review and editing, Armin Knotzer: Investigation, Writing - review and editing, Roberta Pernetti: Investigation, Writing - review and editing.

\section{Declaration of competing interest}

The authors declare that they have no known competing financial interests or personal relationships that could have appeared to influence the work reported in this paper.

\section{Acknowledgments}

This research was done in the framework of the IEA EBC Annex 67 Energy Flexible Buildings. The authors would like to thank the operating agent and members for their engagement. National contributions were supported by national participants who would like to thank their funding agencies. The Dutch participation to the IEA EBC Annex 67 was supported by the Dutch Enterprise Agency (RVO). The Spanish contribution was supported by the GEIDI Project (ref. TIN2016-78473-C3-3-R) financed by the Ministry of Economy and Competitiveness of Spain.

\section{Appendix. list of key workshops in seven countries}

CLIMA 2016 workshop: Grid-Supportive Buildings - Opportunities and Challenges. Aalborg, Denmark, May 2016.

The evolution of buildings: from the NZEB target towards energy flexibility. EREC \& Annex 67 Seminar, Bolzano, Italy, October 2016.

Energy Flexible Buildings - Potential and Performance. Vienna, Austria, September 2017.

Energy Flexibility in buildings: a key asset in the future energy system. Barcelona, Spain, March 2018. 
Urban Energy Innovation. Delft, The Netherlands, May 2018. European Sustainable Energy Week workshop. Brussels, Belgium, June 2018.

FlexForward. Den Bosch, The Netherlands, June 2018.

Urban Energy Platform event. Delft, The Netherlands, May 2019. European Sustainable Energy Week workshop. Brussels, Belgium, June 2019.

\section{References}

ARERA, 2018. Reccomendation 02.08.2018: deliberazione dell'autorita 300/2017/R/ EEL, relative al progetto pilota per la partecipazione di unita virtuali miste al mercato per il servizio di dispacciamento)MSD). ARERA (National regulation Authority for Energy, Grid and Environment), Italy.

Beerepoot, M., 2007. Energy Policy Instruments and Technical Change in the Residential Building Sector. PhD. Thesis. IOS Press:Amsterdam, TU Delft, The Netherlands, ISBN 978-1-58603-811-3.

Behrangrad, M., 2015. A review of demand side management business models in the electricity market. Renew. Sustain. Energy Rev. 47 (C), 270-283.

Bertoldi, P., Boza-Kiss, B., 2017. Analysis of barriers and drivers for the development of the ESCO markets in Europe. Energy Policy 107, 345-355.

Bertoldi, P., Diluiso, F., Castellazzi, L., Labanca, N., Serrenho, T., 2018. Energy Consumption and Energy Efficiency Trends in the EU-28 2000-2015. JRC Report, European Commission.

BMNT/BMVIT, 2018. Mission 2030 - Austrian Climate and Energy Strategy, Federal Ministry for Sustainability and Tourism (BMNT) and Federal Ministry for Transport, Innovation and Technology (BMVIT). Vienna, September 2018. https://mission 2030.info/wp-content/uploads/2018/10/Klima-Energiestrategie_en.pdf. (Accessed 19 July 2019).

BMVIT, 2017. ENERGY Research and Innovation Strategy for Austria, Summary, Federal Ministry for Transport, Innovation and Technology (BMVIT). Vienna. https://nachha ltigwirtschaften.at/resources/e2050_pdf/E-Forschung_Kurzfassung_englisch_v2.pdf. (Accessed 19 July 2019).

Chiaroni, D., Frattini, F., Besozzi, G., di Lieto, A., 2018. In: Electricity market report. Italy. http://www.energystrategy.it/area-riservata/electricity-market-report.html. (Accessed 19 July 2019).

Copenhagen Capacity, 2018. Denmark ready to fund large-scale energy storage projects. Copenhagen, Denmark. https://www.copcap.com/newslist/2018/denmark-readyto-fund-large-scale-energy-storage-projects. (Accessed 28 October 2019).

Danish Government, 2013. The Danish Climate Policy Plan - towards a Low Carbon Society. The Ministry of Climate, Energy and Building, Copenhagen, Denmark. https ://ens.dk/sites/ens.dk/files/Analyser/danishclimatepolicyplan_uk.pdf. (Accessed 19 July 2019).

De Groote, M., Rapf, O., 2015. The Active Role of Buildings in a Transforming Energy Market. Building Performance Institute Europe, Brussels. Discussion paper.

Denholm, P., Hand, M., 2011. Grid flexibility and storage required to achieve very high penetration of variable renewable electricity. Energy Policy 39 (3), 1817-1830.

EC, 2016. Clean Energy for All Europeans, Communication from the Commission to the European Parliament, the Council, the European Economic and Social Committee, the Committee of the Regions and the European Investment Bank. European Commission, COM/2016/0860 final.

EC, 2018. Clean Energy For All Europeans. European Commission. https://ec.europa eu/energy/en/topics/energy-strategy-and-energy-union/clean-energy-all-europe ans. (Accessed 19 July 2019).

EC, 2019. National Energy and Climate Plans (NECPs). European commission. https://ec. europa.eu/energy/en/topics/energy-strategy-and-energy-union/governance-ener gy-union/national-energy-climate-plans. (Accessed 28 October 2019).

EED, 2018. Directive (EU) $2018 / 2002$ of the European parliament and of the council of 11 December 2018 amending directive 2012/27/EU on energy efficiency (Text with EEA relevance), PE/54/2018/REV/1. http://data.europa.eu/eli/dir/2018/2002/oj. (Accessed 19 July 2019).

Energi-, Forsynings- og Klimaministeriet, 2018. Denmark's draft integrated national energy and climate plan. Copenhagen, Denmark. https://ens.dk/sites/ens.dk/files/ EnergiKlimapolitik/denmarks_draft_integrated_energy_and_climate_plan.pdf. (Accessed 28 October 2019).

Energy Storage NL, 2019. Nationaal Actieplan Energieopslag en Conversie 2019. htt ps://www.energystoragenl.nl/nationaal-actieplan-energieopslag-en-conversie-2019. (Accessed 28 October 2019).

EPBD, 2018. Directive (EU) 2018/844 of the European Parliament and of the Council of 30 May 2018 amending Directive 2010/31/EU on the energy performance of buildings and Directive 2012/27/EU on energy efficiency (Text with EEA relevance). http://data.europa.eu/eli/dir/2018/844/oj. (Accessed 19 July 2019).

GEU, 2018. Regulation (EU) 2018/1999 of the European Parliament and of the Council of 11 December 2018 on the Governance of the Energy Union and Climate Action, Amending Regulations (EC) No 663/2009 and (EC) No 715/2009 of the European Parliament and of the Council, Directives 94/22/EC, 98/70/EC, 2009/31/EC, 2009/ 73/EC, 2010/31/EU, 2012/27/EU and 2013/30/EU of the European Parliament and of the Council, Council Directives 2009/119/EC and (EU) 2015/652 and Repealing Regulation (EU) No 525/2013 of the European Parliament and of the Council (Text with EEA relevance), PE/55/2018/REV/1. http://data.europa.eu/eli/reg/2018/1 999/oj. (Accessed 19 July 2019).
Giordano, V., Meletiou, A., Covrig, C.F., Mengolini, A., Ardelean, M., Fulli, G., Jimenez, M.S., Filiou, C., 2013. Smart Grid Projects in Europe: Lessons Learned and Current Developments. JRC Scientific and policy reports, Luxembourg.

Guerra-Santin, O., 2010. Actual Energy Consumption in Dwellings; the Effect of Energy Performance Regulations and Occupant Behaviour. PhD. Thesis. IOS Press: Amsterdam, TU Delft, The Netherlands, ISBN 978-1-60750-651-5.

Heat Law, 2019. Warmtewet, law repository Overheid.nl. https://wetten.overheid.nl/B WBR0033729/2019-07-01. (Accessed 28 October 2019).

Heleno, M., Matos, M.A., Lopes, J.A.P., 2016. A bottom-up approach to leverage the participation of residential aggregators in reserve services markets. Electr. Power Syst. Res. 136, 425-433.

Hendry, C., Harborne, P., Brown, J., 2007. Niche entry as a route to mainstream innovation: learning from the phosporic acid fuel cell in stationary power. Technology Analysis and Strategic Management 19 (4), 403-425.

HM Government, 2016. Smart Energy Research: BEIS Consumer Panel. Department for Business, Energy \& Industrial Strategy, London. (Crown Copyright).

HM Government, 2017. The Clean Growth Strategy: Leading the Way to a Low Carbon Future. Department for Business, Energy and Industrial Strategy, London. Crown Copyright. https://assets.publishing.service.gov.uk/government/uploads/system/ uploads/attachment_data/file/700496/clean-growth-strategy-correction-april-2018. pdf. (Accessed 28 October 2019).

HM Government, 2017. Upgrading Our Energy System: Smart Systems and Flexibility Plan. Department for Business, Energy and Industrial Strategy, London (Crown Copyright).

HM Government, 2018. Upgrading Our Energy System: Smart Systems and Flexibility Plan: Progress Update. Department for Business, Energy and Industrial Strategy, London (Crown Copyright).

IDAE, 2019. Guía de Tramitacion del Autoconsumo. IDAE, Spain. April 2019. http s://www.idae.es/en/node/13679. (Accessed 19 July 2019).

IEA, 2019. Buildings: tracking clean energy progress. https://www.iea.org/tcep/b uildings/. (Accessed 19 July 2019).

IEA, 2019. Global Engagement - Denmark. https://www.iea.org/countries/Denmark/. (Accessed 28 October 2019).

IEA DSM Task 25, 2018. http://www.ieadsm.org/task/task-25-business-models-for -a-more-effective-uptake/. (Accessed 19 July 2019).

IEA EBC Annex 67, 2019. Energy Flexible Buildings. http://www.annex67.org. (Accessed 19 July 2019).

Jensen, S.Ø., Marszal-Pomianowska, A., Lollini, R., Pasut, W., Knotzer, A., Engelmann, P., Stafford, A., Reynders, G., 2017. IEA EBC Annex 67 energy flexible buildings. Energy Build. 155, 25-34.

Jensen, S.Ø., Parker, J., Engelmann, P., Marszal, A.J. (Eds.), 2019. Examples of Energy Flexibility in Buildings, IEA EBC Annex 67 Report. Danish Technological Institute.

Kemp, R., 1994. Technology and the transition to environmental sustainability: the problem of technological regime shifts. Futures 26 (10), 1023-1046.

Kemp, R.E., Schot, J., Hoogma, R., 1998. Regime shifts to sustainability through processes of niche formation: the approach of strategic niche management. Technol. Anal. Strateg. Manag. 10 (2), 175-198.

Koirala, B., Hakvoort, R., 2017. Chapter 18 - integrated community-based energy systems: aligning technology, incentives, and regulations A2. In: Sioshansi, F.P. (Ed.), Innovation and Disruption at the Grid's Edge. Academic Press, pp. 363-387.

Laffont-Eloire, K., Peraudeau, N., Petit, S., Bourdeau, M., Joumni, H., Belaid, F., Grasset, H., Marchi, F., Dall'Oro, L., Pratlong, M., La, X.W., 2019. Sustainable Business Models for the Deep Renovation of Buildings, Horizon 2020 Project STUNNING (GA No. 768287), Final Report. https://www.stunning-project.eu/. (Accessed 28 October 2019).

Li, R., Dane, G., Finck, C., Zeiler, W., 2017. Are building users prepared for energy flexible buildings? - a large-scale survey in The Netherlands. Appl. Energy 203, 623-634.

Ma, Z., Dalmacio Billanes, J., Nørregard Jørgensen, B., 2017. Aggregation potentials for buildings-business models of demand response and virtual power plants. Energies 10, 1646. https://doi.org/10.3390/en10101646.

Ma, Z., Parker, J., Mlecnik, E., Jørgensen, B.N., Li, R., Pernetti, R., Vigna, I., Ma, T. Knotzer, A., Petersen, S., Hedegaard, R.E., Pedersen, T.H., Schultz, M.J., Korsgaard, J., 2019. IEA Annex 67 Energy Flexible Buildings Internal ReportStakeholders' Perspectives on Energy Flexible Buildings. University of Southern Denmark. IEA EBC Annex 67 report.

Meadowcroft, J., 2009. What about the politics? Sustainable development, transition management, and long term energy transitions. Policy Sci. 42 (4), 323-340.

MED, 2017. National Decree 19.06.2017: PANZEB: National Plan for the Uptake of Nearly-Zero Energy Buildings. Minister of Economic Development, Italy.

MED, 2018. Decree n.28/2011: Attuazione della direttiva 2009/28/CE sulla promozione dell'uso dell'energia da fonti rinnovabili, recante modifica e successiva abrogazione delle direttive 2001/77/CE e 2003/30/CE. Minister of Economic Development, Italy (in Italian).

Mlecnik, E., 2014. Which factors determine the success of strategic niche developments? Reflections from the emergence of a passive house network. Constr. Innovat. 14 (1), 36-51.

Mlecnik, E., 2013. Innovation Development for Highly Energy-Efficient Housing; Opportunities and Challenges Related to the Adoption of Passive Houses. PhD. Thesis. IOS Press:Amsterdam, TU Delft, The Netherlands, ISBN 978-1-61499-236-3.

Murphy, L.C., 2016. Policy Instruments to Improve Energy Performance of Existing Owner Occupied Dwellings, PhD. Thesis. TU Delft, The Netherlands, ISBN 978-9492516-18-3.

PAE, 2017. Italian Energy Efficiency Action Plan, European Commission, Brussels accessed. https://ec.europa.eu/energy/sites/ener/files/documents/it_neeap_20 17_en.pdf. (Accessed 28 October 2019). 
Annex 67: energy flexible buildings energy flexibility as a key asset in a smart building future, position paper of the IEA energy in buildings and communities program (EBC) Annex 67 energy flexible buildings. In: Pernetti, R., Reynders, G., Knotzer, A. (Eds.), 2017. Available on-line: www.annex67.org. (Accessed 19 July 2019).

PNIEC, 2019. Plan Nacional Integrado de Energia y Clima (PNIEC) 2021-2030, IDAE. June 2019. Available on-line: https://www.idae.es/en/node/13613. (Accessed 19 July 2019).

Raven, R.P.J.M., 2005. Strategic Niche Management for Biomass, PhD. Thesis. Eindhoven University of Technology, The Netherlands.

RED, 2018. Directive (EU) 2018/2001 of the European Parliament and of the Council of 11 December 2018 on the promotion of the use of energy from renewable sources (Text with EEA relevance.), PE/48/2018/REV/1. Available on-line: http://data. europa.eu/eli/dir/2018/2001/oj. . (Accessed 19 July 2019).

REFER, 2019. Reduccio Energetica i Flexibilitat en Edificis en Rehabilitacio (REFER), COMRDI15-1-0036, funded by the European Regional Development Fund (FEDER) under the RIS3CAT Energy Community. Available online: https://refer.upc.edu/ca. (Accessed 19 July 2019).

Rotmans, J., Kemp, R., van Asselt, M., Geels, F., Verbong, G., Molendijk, K., 2000. Transities en transitiemanagement: de casus van een emissiearme energievoorziening. ICIS, MERIT, Maastricht, The Netherlands.

Schot, J., Geels, F.W., 2008. Strategic niche management and sustainable innovation journeys: theory, findings, research agenda, and policy. Technol. Anal. Strateg. Manag. 20 (5), 537-554.

Schultz, M.J., 2019. Chapter 4 - aggregators. In: Ma, Z., et al. (Eds.), IEA Annex 67 Energy Flexible Buildings Internal Report-Stakeholders' Perspectives on Energy Flexible Buildings. University of Southern Denmark.

Seidl, R., von Wirth, T., Krütli, P., 2019. Social acceptance of distributed energy systems in Swiss, German, and Austrian energy transitions. Energy Res. Soc. Sci. 54, 117-128.

Smith, A., 2007. Translating sustainabilities between green niches and socio-technical regimes. Technol. Anal. Strateg. Manag. 19 (4), 427-450.

SRI, 2018. Support for Setting up a Smart Readiness Indicator for Buildings and Related Impact Assessment. Study Ordered and Paid by the European Commission,
Directorate-General for Energy. Flemish Institute for Technological Research NV, Mol, Belgium. Contract no. ENER/C3/2016-554/SI2.749248. https://smartreadi nessindicator.eu/.

State of Green, 2018. New Danish energy agreement secured: 50 percent of Denmark's energy needs to be met by renewable energy in 2030. . Copenhagen, Denmark. htt ps://stateofgreen.com/en/partners/state-of-green/news/new-danish-energy-agree ment-a-green-focus-towards-2030/. (Accessed 28 October 2019).

Stutvoet, E., 2018. Energietransitie: omarm de complexiteit; ontwikkeling en grootschalige toepassing van energieneutrale renovatieconcepten voor de naoorlogse sociale woningvoorraad. PhD. TU Delft, The Netherlands, ISBN 978-946366-070-9 (in Dutch).

TKI Urban Energy, 2015. Kennis- en Innovatieagenda 2016 TKI URBAN ENERGY Solar \& Smart Energy Solutions. In: Dutch). Stichting TKI Urban Energy, Utrecht, The Netherlands.

TP SGA, 2019. Smart Grids Austria: Mission Statement, Goals and Tasks available online: https://www.smartgrids.at/english.html. (Accessed 29 May 2019).

Van de Belt, H., Rip, A., 1984. Technologie-ontwikkeling: Het Nelson-Winter/Dosi Model. University of Leiden, The Netherlands.

Verbong, G., Geels, F.W., Raven, R., 2008. Multi-niche analysis of dynamics and policies in Dutch renewable energy innovation journeys (1970-2006): hype-cycles, closed networks and technology-focused learning. Technol. Anal. Strateg. Manag. 20 (5), 555-573.

VRWI, 2014. VRWI Toekomstverkenningen 2025, Studiereeks 26. Vlaamse Raad voor Wetenschap en Innovatie, Brussels, Belgium (in Dutch).

WetVET, 2018. Besluit van 26 april 2018 tot vaststelling van het tijdstip van inwerkingtreding van de Wijziging van de Elektriciteitswet 1998 en van de Gaswet (voortgang energietransitie). Staatsblad van het Koninkrijk der Nederlanden 129, 8. May 2018 (in Dutch).

Woei, I., 2007. Using Strategic Niche Management and Bricolage for the Diffusion of Autonomous PV Systems. graduation thesis University Utrecht/TU Delft/Cartesius Institute, The Netherlands. 